\title{
Metabolic and Hormonal Responses to Glucose and Glucagon in Patients with Infantile Malnutrition
}

\author{
R. D. G. Milner $[36,37]$ \\ Medical Research Council Tropical Metabolism Research Unit, Kingston, Jamaica
}

\begin{abstract}
Extract
The interrelations of plasma levels of glucose, free fatty acids (FFA), $\alpha$-amino nitrogen $(\alpha$-aaN), insulin, and growth hormone (GH) were studied in 26 malnourished infants shortly after admission to the hospital and again several weeks later when they had recovered. In the sick children (SC) fasting levels of FFA and GH were high, and insulin and $\alpha$-aaN were low; with recovery FFA, $\alpha$-aaN and insulin levels became normal, and $\mathrm{GH}$ levels fell. No change occurred in glucose levels.

Ten infants were given glucose $(0.5 \mathrm{~g} / \mathrm{kg}$ body weight) intravenously on the 1st or 2nd day after admission and again 6-12 weeks later. Glucose tolerance was impaired in the sick group and, although improved, was not normal when the children had recovered from the nutritional insult. Insulin secretion was stimulated by glucose in those that had recovered ( $\mathrm{RC}$ ), but not in the SC. No significant change occurred in either FFA or $\alpha$-aaN levels in these groups.

Nine infants received glucagon $(0.1 \mathrm{mg} / \mathrm{kg}$ body weight) intravenously on the 2nd to 6th day after admission and again 6-12 weeks later. Glucagon caused a rise in glucose levels that were greater in $\mathrm{RC}$ than in $\mathrm{SC}$ but did not cause a significant change in insulin levels in either group. Free fatty acid levels were higher in SC throughout the test, but in both groups FFA levels responded similarly to glucagon administration, falling 10 and $60 \mathrm{~min}$ after the injection.

Changes in $\mathrm{GH}$ levels in plasma after glucose or glucagon administration were compared with the changes caused by five venepunctures in $\mathrm{RC}$. Venepunctures and glucose caused similar rises in GH levels, but glucagon caused a greater rise than either. It was concluded that the stress of repeated venepunctures caused a rise in GH levels in plasma in all three tests, but that, independent of this, glucagon stimulated GH secretion.
\end{abstract}

\section{Speculation}

Insulin secretion is impaired in infantile malnutrition and does not improve at the same rate as clinical recovery occurs, suggesting that normal $\beta$ cell function is not essential for rapid growth. The role of growth hormone in malnutrition is not clear, but it appears to be involved more in the metabolic adaptation to malnutrition than in the control of growth.

\section{Introduction}

The hormonal adaptation to malnutrition is complex [15] and study of the endocrine responses to infantile malnutrition can be doubly rewarding, for from it may come information on the mechanism of adaptation to starvation in infancy and subsequently on the hormonal aspects of "catch-up" growth.

Children with kwashiorkor have a poor glucose tol- 
erance $[3,4,7]$ whereas children with marasmus may have a normal $[4,7]$ or abnormal tolerance [22]. $\mathrm{Pa}$ tients with these diseases have low fasting insulin levels [3, 7] and high levels of GH [24, 25], both of which return to normal on recovery $[7,24,25]$. No systematic study of insulin and GH levels in the same malnourished child has been reported, and the relation of the two hormones to each other or to changes in blood glucose during recovery from malnutrition is a matter of conjecture.

The present study sought to investigate this problem in two ways. Recovery from infantile malnutrition is characterized by an increased rate of growth which, in children admitted to this Unit, is approximately 15 times that of a normal child of the same age or 5 times that of a normal child of the same weight or height [2]. The metabolic and hormonal responses to glucose and glucagon were studied in malnourished children shortly after admission and again, several weeks later, when they were past the peak of their catcli-up growth. The response to intravenous glucose served to characterize the infants for comparison with other reports and to test if hyperglycemia stimulated secretion of insulin and caused a rise in GH levels as it does in the newborn [6,30], or a fall, as seen in the adult [26]. Glucagon was used because it stimulates insulin secretion both by direct action on the $\beta$ cell [27] and by causing hyperglycemia. Also, glucagon causes a rise in GH levels in the newborn [16], and it was of interest to see if it would do this in older infants who were of a similar size. By studying each child twice, it was possible to use each subject as his own control.

\section{Subjects and Methods}

\section{Subjects}

The children studied were patients admitted to the Unit for investigation and treatment of infantile malnutrition. On admission a careful explanation was given to the parent or guardian and permission was obtained for the tests to be performed. Twenty-six children were studied; the ages ranged between 6 and 17 months with one exception of 27 months. Clinical classification was made on the basis of two objective criteria: weight and edema. Ten had edema and were less than $60 \%$ of the 50th percentile for weight [20]; these may be described as having had marasmic-kwashiorkor, the commonest type of malnourished child admitted to the Unit. Nine had marasmus; i.e., they were less than $60 \%$ of their expected weight but had no edema. Five had edema and were more than $60 \%$ of their expected weight; they had kwashiorkor. Two had no edema and were 61 and $66 \%$ of their expected weight. Each child was treated with milk feeds of increasing strength and for most of the stay received approximately $150 \mathrm{kcal}$ and $3 \mathrm{~g}$ protein $/ \mathrm{kg}$ body weight $/ 24 \mathrm{hr}$. Folic acid, ferrous sulfate, and vitamin supplements were given routinely; infection was treated when present. Each child was weighed daily.

\section{Investigations}

Blood samples were collected at various times after an overnight fast $(8-9 \mathrm{hr})$. In six recovered patients, five fasting blood samples were collected in $1 \mathrm{hr}$, at 0 , $3,10,30$, and $60 \mathrm{~min}$. Most samples were collected by venepuncture; a few were capillary blood.

Ten patients (seven boys, three girls; six marasmickwashiorkor, two marasmus, one kwashiorkor, one first degree malnutrition), who had fasted overnight, received glucose $(0.5 \mathrm{~g} 50 \%$ glucose $/ \mathrm{kg}$ body weight) by intravenous injection on the 1st or 2nd day after admission. Blood samples were drawn before $(0 \mathrm{~min})$ and at $3,10,30$, and $60 \mathrm{~min}$ after the injection. The test was repeated 6-12 weeks later when the patients had recovered clinically.

Nine patients (seven boys, two girls; five marasmickwashiorkor, two marasmus, two kwashiorkor), who had fasted overnight, received glucagon $(0.1 \mathrm{mg} / \mathrm{kg}$ body weight) by intravenous injection on the 2nd to 6th day after admission and again 6-12 weeks later. Blood samples were collected as clescribed for intravenous glucose tests.

\section{Methods}

All blood samples were collected in bottles contain. ing heparin and fluoride and were centrifuged within $30 \mathrm{~min}$. Glucose and FFA levels were estimated the same day. Aliquots of plasma were stored at $-20^{\circ}$ until $\alpha$-aaN, insulin, and GH levels were measured. For duplicate determinations of glucose, FFA, $\alpha$-aaN, insulin, and GH, $300 \mu \mathrm{l}$ plasma sufficed, thus making feasible repeated blood samples on one infant on 1 day.

Methods used were as follows: glucose, by a glucose oxidase assay [10]; FFA, by a modification [28] of the method of Novak [21]; $\alpha$-aaN, by the method of Stein and Moore [29]; insulin, by immunoassay [8], using an ox insulin standard and an antibody, which did not discriminate between ox and human insulin [33]. Growth hormone in the plasma was measured by radioimmunoassay with preprecipitated antibody, filtration for the separation of "free" and "bound" hor- 
mone, and a human GH standard [34]. Standard GH solutions and plasma diluted in parallel in the assay.

Statistical analyses were done by Student's $t$ test. Where the difference between two values is stated to be significant without further qualification, $P<0.05$.

\section{Results}

\section{Growth during Recovery from Malnutrition}

Figure 1 shows the average growth rate of the 26 children during hospitalization. During the Ist week, when the initial intravenous glucose and glucagon tests were performed, the rate of weight gain ranged from -19.2 to $+5.4 \mathrm{~g} / \mathrm{kg} / 24 \mathrm{hr}$. Catch-up growth occurred mainly in the 2 nd to 5 th weeks. The second glucose or glucagon test was performed when the child had passed the peak growth rate but was still growing more rapidly than normally and was close to his expected weight for height.

\section{Fasting Levels of Metabolites and Hormones}

Table I shows the fasting levels of glucose, FFA, $\alpha$-aaN, insulin, and $\mathrm{GH}$ in 19 pairs of blood samples. These were the initial samples from the glucose and glucagon tests and came from 15 infants, since 4 had both tests. There was no significant change in glucose levels with recovery. Insulin and $\alpha$-aaN levels rose, and FFA and GH levels fell when the children had recovered from malnutrition. Figure 2 is a scattergram showing fasting GH plotted against length of stay in

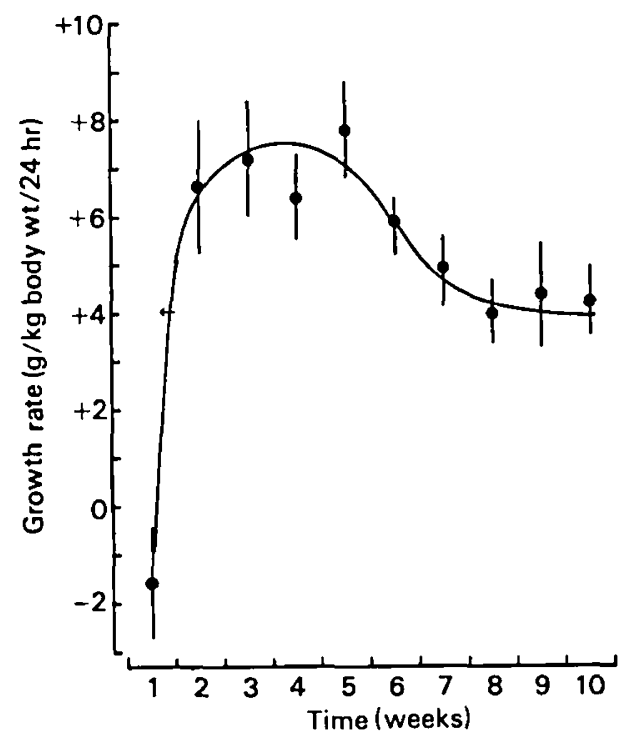

Fig. 1. Mean \pm SEM growth rate of the 26 malnourished infants studied.
Table I. Plasma levels of metabolites and hormones in fasted malnourished infants

\begin{tabular}{lcc}
\hline \multirow{2}{*}{$\begin{array}{c}\text { Levels of metabolite } \\
\text { or bormone in plasma }\end{array}$} & \multicolumn{2}{c}{ Time after admission to hospital } \\
\cline { 2 - 3 } & 1-6 days & 6-12 weeks \\
\hline Glucose, mg/100 ml & $67 \pm 4^{1}(19)^{2}$ & $73 \pm 3(19)$ \\
FFA, $\mu$ moles/liter & $707 \pm 91(19)$ & $238 \pm 39(19)^{3}$ \\
$\alpha$-Amino nitrogen, & $2.6 \pm 0.2(19)$ & $3.2 \pm 0.2(19)^{3}$ \\
mmoles/liter & & \\
Insulin, $\mu \mathrm{U} / \mathrm{ml}$ & $7 \pm 1(19)$ & $12 \pm 1(19)^{3}$ \\
GH, ng/ml & $24.5 \pm 4.6(17)$ & $8.7 \pm 1.2(19)^{3}$ \\
\hline
\end{tabular}

${ }^{1}$ Mean \pm SEM.

2 Number of observations indicated in parentheses.

$3 p<0.05$ when the sick and recovered groups were compared.

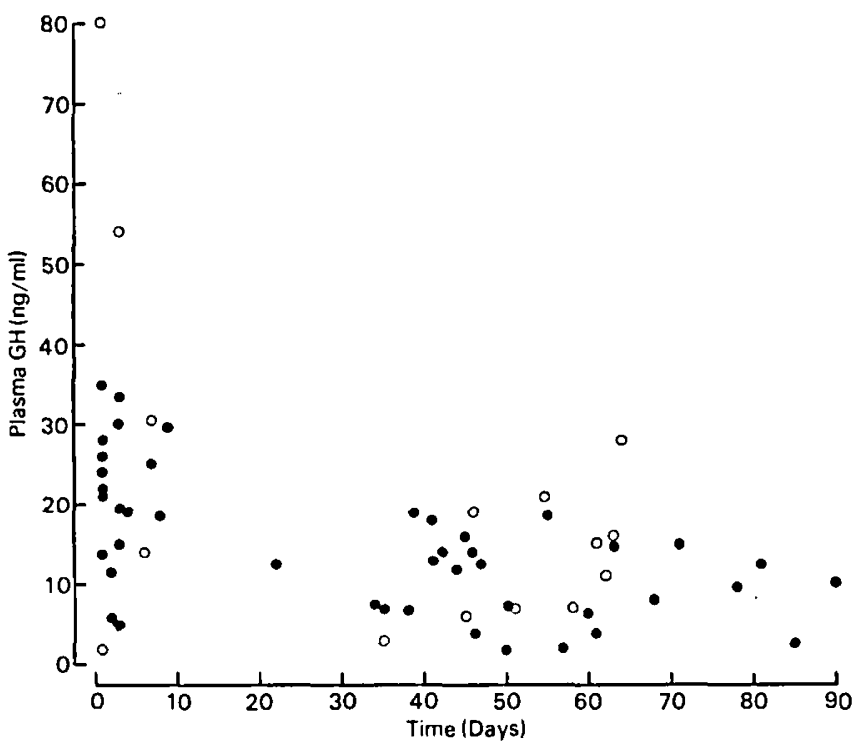

Fig. 2. Scattergram showing fasting GH levels in plasma plotted against length of stay in hospital of malnourished infants. : Boys. O: Girls.

the hospital. The rate of fall of fasting $\mathrm{GH}$ levels could not be assessed accurately because of the paucity of information between days 10 and 30 .

\section{Intravenous Glucose}

Too few glucose determinations were made after the intravenous glucose load to allow an estimate of the disappearance rate of glucose $(k)$ to be made in each case. The mean levels of glucose show that glucose tolerance improved on recovery (Table II). From the mean levels an approximate glucose disappearance rate for the sick children (SC) was $k_{t} 1.0 \% \mathrm{~min}^{-1}$ and for the recovered children (RG), $1.6 \% \mathrm{~min}^{-1}$. Levels of FFA were significantly higher in SC at all times except in the 60 -min sample. No significant change was seen in either group after the glucose load. Administration 
of intravenous glucose had no effect on $\alpha$-aaN levels, and, although these levels tended to be higher in RC, the difference was significant only at $30 \mathrm{~min}$. There was no insulin response to glucose in the SC whereas a rise occurred at $3 \mathrm{~min}$ in RC. Levels of insulin in RC were significantly higher than those in SC at 10 and 30 min, but fell to fasting levels at $60 \mathrm{~min}$. In both SC and $\mathrm{RC}$ levels of $\mathrm{GH}$ rose after glucose administration. The rise in GH levels observed in RC at $3 \mathrm{~min}$ was significantly greater than that seen in SC $(P<0.025)$; and the subsequent fall was slower, returning to fasting levels at $30 \mathrm{~min}$ in the SC but remaining significantly above the fasting level in the RC at 60 min.

\section{Intravenous Glucagon}

The intravenous injection of glucagon had no clinical effect on any child. Levels of glucose rose to a plateau by $30 \mathrm{~min}$ in the $\mathrm{SC}$ and to a peak at $30 \mathrm{~min}$ in RC (Table III). The maximal rise in glucose levels after glucagon administration was significantly greater in RC than in SC. In RC, levels of glucose fell significantly from 30 to $60 \mathrm{~min}$. Levels of FFA were higher in SC throughout the test. In both groups, glucagon caused a rise between 0 and $10 \mathrm{~min}$, which was not significant, followed by a gradual fall at 30 and 60 min. The fall in FFA level between 10 and $60 \mathrm{~min}$ was significant in both groups. Levels of $\alpha$-aaN were similar in both groups and did not change after intravenous glucagon. There was no significant rise in levels of insulin in either group at any time after the injection of glucagon. Also, neither the sum of the rises above the fasting level nor the maximal rise in the test was significant. Levels of $\mathrm{GH}$ were higher throughout the test in SC. In both groups there was a rise in GH levels after injection of glucagon reaching a maximal elevation at $10 \mathrm{~min}$ with a subsequent fall to fasting levels by the end of the test.

\section{Effect of Five Venepunctures}

The effect of five venepunctures alone, on the concentrations of metabolites and hormones measured, was studied in six recovered fasting children. The change from fasting levels of each of the variables during the 60-min period is shown in Table IV. The high

Table II. Metabolic and hormonal response of malnourished infants to intravenous glucose injection

\begin{tabular}{|c|c|c|c|c|c|c|}
\hline \multirow{2}{*}{$\begin{array}{c}\text { Levels of metabolite } \\
\text { or hormone in } \\
\text { plasma }\end{array}$} & \multirow{2}{*}{ Condition } & \multicolumn{5}{|c|}{ Time, $\mathrm{min}$, before or after glucose challenge, $0.5 \mathrm{~g} / \mathrm{kg}$ body wt } \\
\hline & & 0 & 3 & 10 & 30 & 60 \\
\hline \multirow[t]{2}{*}{ Glucose, mg/100 ml } & Sick & $72 \pm 61(10)^{2}$ & $333 \pm 19(10)$ & $253 \pm 15(10)$ & $190 \pm 16(10)$ & $150 \pm 17(10)$ \\
\hline & Recovered & $71 \pm 4(10)$ & $275 \pm 15(10)^{3}$ & $208 \pm 13(10)^{2}$ & $142 \pm 8(10)^{3}$ & $94 \pm 4(10)^{2}$ \\
\hline \multirow[t]{2}{*}{ FFA, رmoles/liter } & Sick & $617 \pm 131$ (10) & $586 \pm 132(10)$ & $585 \pm 135(10)$ & $573 \pm 150(10)$ & $481 \pm 126(10)$ \\
\hline & Recovered & $192 \pm 38(10)^{2}$ & $166 \pm 39(9)^{2}$ & $207 \pm 35(10)$ & $170 \pm 55(10)^{2}$ & 202 土 $66(10)$ \\
\hline \multirow{4}{*}{$\begin{array}{l}\alpha \text {-Amino nitrogen, } \\
\text { mmoles/liter } \\
\text { Insulin, } \mu \mathrm{U} / \mathrm{ml}\end{array}$} & Sick & $2.2 \pm 0.1(10)$ & $2.4 \pm 0.2(10)$ & $2.4 \pm 0.3(10)$ & $2.2 \pm 0.2(10)$ & $2.4 \pm 0.3(10)$ \\
\hline & Recovered & $3.2 \pm 0.5(10)$ & $3.0 \pm 0.4(9)$ & $3.2 \pm 0.4(10)$ & $3.2 \pm 0.4(10)$ & $2.7 \pm 0.3(10)$ \\
\hline & Sick & $7 \pm 1(10)$ & $11 \pm 3(10)$ & $9 \pm 1(10)$ & $8 \pm 1(9)$ & $10 \pm 2(10)$ \\
\hline & Recovered & $10 \pm 2(10)$ & $36 \pm 8(9)^{2}$ & $19 \pm 3(10)^{3}$ & $17 \pm 3(10)$ & $11 \pm 2(10)$ \\
\hline \multirow{2}{*}{$\mathrm{GH}, \mathrm{ng} / \mathrm{ml}$} & Sick & $24.8 \pm 8.6(8)$ & $29.3 \pm 7.4(10)$ & $31.2 \pm 7.0(10)$ & $21.8 \pm 4.5(9)$ & $21.1 \pm 6.2(10)$ \\
\hline & Recovered & $6.9 \pm 1.3(10)$ & $17.6 \pm 2.9(9)$ & $11.4 \pm 3.0(10)^{3}$ & $12.4 \pm 3.7(10)$ & $11.0 \pm 2.1(10)$ \\
\hline
\end{tabular}

1 Mean \pm sEx.

- Number of observations indicated in parentheses.

i $P<0.05$ when the recovered and sick groups were compared.

Table III. Metabolic and hormonal response of malnourished infants to intravenous glucagon injection

\begin{tabular}{|c|c|c|c|c|c|c|}
\hline \multirow{2}{*}{$\begin{array}{c}\text { Levels of metabolite } \\
\text { or hormone } \\
\text { in plasma }\end{array}$} & \multirow{2}{*}{ Condition } & \multicolumn{5}{|c|}{ Time, $\mathrm{min}$, before or after glucagon challenge, $0.1 \mathrm{mg} / \mathrm{kg}$ body wt } \\
\hline & & 0 & 3 & 10 & 30 & 60 \\
\hline Glucose, $\mathrm{mg} / 100 \mathrm{ml}$ & $\begin{array}{l}\text { Sick } \\
\text { Recovered }\end{array}$ & $\begin{array}{l}62 \pm 51(9)^{2} \\
75 \pm 3(9)^{2}\end{array}$ & $\begin{aligned} 75 & \pm 6(9) \\
103 & \pm 8(9)\end{aligned}$ & $\begin{aligned} 92 & \pm 8(9) \\
123 & \pm 9(9)\end{aligned}$ & $\begin{array}{l}116 \pm 10(9) \\
167 \pm 10(9)\end{array}$ & $\begin{array}{l}118 \pm 10(9) \\
138 \pm 15(9)\end{array}$ \\
\hline FFA, $\mu$ moles/Jiter & $\begin{array}{l}\text { Sick } \\
\text { Recovered }\end{array}$ & $\begin{array}{l}807 \pm 125(9) \\
289 \pm 69(9)\end{array}$ & $\begin{array}{l}864 \pm 150(9) \\
337 \pm 79(9)\end{array}$ & $\begin{array}{l}896 \pm 156(9) \\
384 \pm 79(9)\end{array}$ & $\begin{array}{l}678 \pm 128(9) \\
221 \pm 51(9)\end{array}$ & $\begin{array}{l}593 \pm 113(9) \\
150 \pm 62(9)\end{array}$ \\
\hline $\begin{array}{l}\alpha-\text { Amino nitrogen, } \\
\text { mmoles/liter }\end{array}$ & $\begin{array}{l}\text { Sick } \\
\text { Recovered }\end{array}$ & $\begin{array}{l}2.9 \pm 0.2(9) \\
3.3 \pm 0.2(9)\end{array}$ & $\begin{array}{l}3.1 \pm 0.2(8) \\
3.1 \pm 0.2(9)\end{array}$ & $\begin{array}{l}3.0 \pm 0.2(9) \\
3.1 \pm 0.2(9)\end{array}$ & $\begin{array}{l}3.1 \pm 0.3(9) \\
2.7 \pm 0.3(9)\end{array}$ & $\begin{array}{l}2.7 \pm 0.2(7) \\
2.5 \pm 0.3(9)\end{array}$ \\
\hline Insulin, $\mu \mathrm{U} / \mathrm{ml}$ & $\begin{array}{l}\text { Sick } \\
\text { Recovered }\end{array}$ & $\begin{array}{r}7 \pm 2(9) \\
12 \pm 2(9)\end{array}$ & $\begin{array}{l}11 \pm 2(9) \\
17 \pm 4(9)\end{array}$ & $\begin{array}{l}12 \pm 4(9) \\
15 \pm 3(9)\end{array}$ & $\begin{array}{l}13 \pm 6(9) \\
17 \pm 2(9)\end{array}$ & $\begin{array}{l}11 \pm 3(9) \\
16 \pm 2(9)\end{array}$ \\
\hline $\mathrm{GH}, \mathrm{ng} / \mathrm{ml}$ & $\begin{array}{l}\text { Sick } \\
\text { Recovered }\end{array}$ & $\begin{array}{l}24.5 \pm 4.5(9) \\
10.7 \pm 1.8(9)\end{array}$ & $\begin{array}{l}34.8 \pm 7.2(8) \\
24.0 \pm 4.6(9)\end{array}$ & $\begin{array}{l}45.4 \pm 9.7(9) \\
29.1 \pm 3.6(9)\end{array}$ & $\begin{array}{l}35.4 \pm 3.1(9) \\
13.9 \pm 2.0(9) 8\end{array}$ & $\begin{array}{l}27.0 \pm 5.0(8) \\
10.6 \pm 1.1(9)\end{array}$ \\
\hline
\end{tabular}

Mean \pm sex.

- Number of observations indicated in parentheses.

$P<0.03$ when the well and sick groups are compared. 
Table $I V$. Change from fasting levels of metabolites and hormones in six infants who had recovered from infantile malnutrition

\begin{tabular}{|c|c|c|c|c|c|}
\hline \multirow{2}{*}{ Level of metabolite or hormone } & \multirow{2}{*}{ Fasting level } & \multicolumn{4}{|c|}{ Change from fasting level at time, min } \\
\hline & & 3 & 10 & 30 & 60 \\
\hline Glucose, $\mathrm{mg} / 100 \mathrm{ml}$ & $61 \pm 10^{1}$ & $+2 \pm 2^{1}$ & $+5 \pm 2$ & $+5 \pm 2$ & $+6 \pm 3$ \\
\hline FFA, $\mu$ moles/liter & $685 \pm 262$ & $+18 \pm 32$ & $+72 \pm 75$ & $+130 \pm 64$ & $+147 \pm 71$ \\
\hline$\alpha$-Amino nitrogen, mmoles/liter & $3.1 \pm 0.3$ & $-0.1 \pm 0.2$ & $+0.2 \pm 0.3$ & $0 \pm 0.2$ & $-0.1 \pm 0.3$ \\
\hline Insulin, $\mu \mathrm{U} / \mathrm{ml}$ & $7 \pm 1$ & $+2 \pm 1$ & $+7 \pm 4$ & $+4 \pm 3$ & $+4 \pm 2$ \\
\hline $\mathrm{GH}, \mathrm{ng} / \mathrm{ml}$ & $10.3 \pm 3.8$ & $+4 \pm 1.6^{2}$ & $+8.6 \pm 1.9^{2}$ & $+1.9 \pm 1.3$ & $-0.9 \pm 0.8$ \\
\hline
\end{tabular}

1 Mean \pm SEM.

2 Change is significant $(P<0.05)$.

mean fasting level of FFA in this group was due to measurements of 1730 and $1235 \mu$ moles/liter in two infants whose intake had been temporarily reduced. The only significant change from fasting levels was in $\mathrm{GH}$, which was raised at 3 and $10 \mathrm{~min}$. Figure 3 shows a comparison of the rise in plasma $\mathrm{GH}$ levels in $\mathrm{RC}$ due to venepuncture alone compared with that due to injection of glucose or glucagon. It was concluded that intravenous glucose did not cause a greater rise in $\mathbf{G H}$ levels than venepuncture alone, but that glucagon did cause a rise in $\mathrm{GH}$ levels greater than that due to venepuncture.

\section{Discussion}

When initial glucose- and glucagon-loading tests were performed, the infants were still undernourished since they were receiving dilute milk feeds, but when the second tests were performed each child was near his expected weight for height and had passed his peak growth rate.

Despite the normality of fasting levels of glucose a deficiency in glucose homeostasis was revealed by glucagon. Glucagon caused a smaller rise in glucose levels in plasma in SC than in RC, which was probably due to decreased hepatic glycogen since glycogenolysis is known to be normal in infants with similar problems [1]. Impaired utilization of glucose in the SC was seen after glucose injection and in the glucose levels 30 and $60 \mathrm{~min}$ after glucagon. High levels of FFA and GH and the absence of a $\beta$-cell response to hyperglycemia contributed to this impairment.

The high levels of FFA in the SC are similar to those seen in patients with kwashiorkor [12]. In patients with marasmus, Lewis et al. [12] found raised FFA levels also, whereas Hadden [7] reported low levels of FFA. In this study, the fasting FFA levels in the four infants ill with marasmus were greater than the mean of the group, being 738, 920, 1000, and 1409 $\mu$ moles/liter. High levels of FFA are associated with

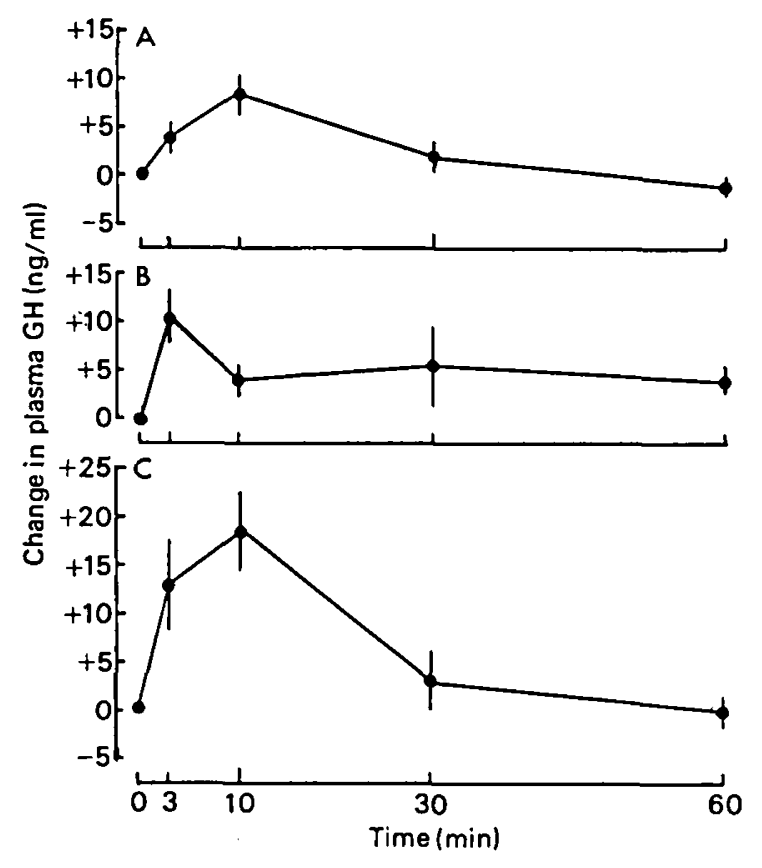

Fig. 3. Mean \pm sEM change from fasting level of GH in plasma in infants who had recovered from malnutrition. $A$ : Six infants who had venepunctures only. $B$ : Ten infants who received intravenous glucose. $C$ : Nine infants who received intravenous glucagon. Further details are given in the text.

increased FFA flux [13], which may also be due to the high GH [31] and low insulin levels in plasma.

By studying the same children twice, it was possible to demonstrate a significant rise in insulin levels in plasma to normal fasting levels on recovery. This did not indicate a return to normal $\beta$ cell function, as revealed by results of both the glucose and glucagon tests. Because of the dual nature of the stimulus to release of insulin by glucagon, it was possible that the failure to demonstrate a significant rise in insulin was due to differences in the timing of the response of the $\beta$ cell in different infants. This was excluded by finding that the maximal insulin rise or the sum of the 
insulin rises above the fasting level was not significant. The insulin response to intravenous glucose showed that clinical recovery was associated with improvement in $\beta$ cell function.

Because of the persistence of what appeared to be high levels of GH in RC, an analysis of all estimations of fasting GH was made. The scattergram (Fig. 2) shows that, although some of the highest values were in girls, there was no clear-cut sex difference. Between the 4 th and 12th weeks the range of levels varied little. It is not possible to state whether the mean fasting $\mathrm{GH}$ level at this time was normal since the fasting $\mathrm{GH}$ level in normal infants aged 1 year is not known. The interpretation of the $\mathrm{GH}$ response to glucose or glucagon is complicated in that the design of the investigations required repeated venepunctures and venepuncture in children has been shown to cause a rise in $\mathrm{GH}$ levels [9]. Control measurements of metabolites and hormones in six recovered children showed that venepunctures caused significant rises in GH levels at 3 and $10 \mathrm{~min}$. The rise in GH level after glucose was similar to that seen after venepunctures alone (Fig. 3), suggesting that the $\mathrm{GH}$ response to glucose was an artefact caused by venepuncture. In contrast, the $\mathrm{GH}$ response to glucagon was greater than that due to glucose or venepuncture, and, allowing for the stimulation by venepunctures after the injection of glucagon, it was apparent that glucagon itself caused a rise in GH levels. It follows that secretion of GH, although stimulated by malnutrition, can be further increased by either the stress of venepuncture or a glucagon challenge.

The malnourished infant resembles the starving normal adult in having low levels of insulin and high levels of GH, and the hypothesis that insulin is the prime signal responsible for fuel control is apt for infancy as well as for adults [5]. The possible permanence of subnormal secretion of insulin makes it important to study these children yet again to clarify whether infantile malnutrition can predispose to adult diabetes mellitus.

Undernutrition or malnutrition in adults as in infants causes similar changes in GH levels. Fasting [26], anorexia nervosa [14], renal failure [32], and proteinlosing enteropathy [23] are all associated with elevated levels of circulating GH. Of more direct relevance to infantile malnutrition may be the fact that babies born small for their gestational age, who are thought to have been malnourished in utero, have high levels of GH [11], while babies born to diabetic mothers, who may have been overnourished in utero, have low levels of GH at birth [30].

Malnutrition of the severity observed in the present study does not result in hyposecretion of $\mathbf{G H}$, as has been suggested by others [17-19].

\section{Summary}

Measurements of levels of glucose, FFA, $\alpha$-amino nitrogen $(\alpha-a a N)$, insulin, and growth hormone in the plasma of malnourished infants revealed low fasting levels of insulin and high levels of FFA and growth hormone on admission to the hospital. After recovery, fasting levels of insulin and FFA became normal and growth hormone levels fell but probably remained above normal. Insulin secretion was stimulated by glucose in the recovered children (RC) but not in the sick children (SC). Glucagon was ineffective in causing insulin release in either group. Secretion of growth hormone was stimulated by glucagon or the stress of venepuncture in both sick and recovered infants.

\section{References and Notes}

1. Alleyne, G. A. O., and Scullard, G. H.: Alterations in carbohydrate metabolism in Jamaican children with severe malnutrition. Clin. Sci., 37: 631 (1969).

2. Asmwortir, A.: Growth rates in children recovering from protein-calorie malnutrition. Brit. J. Nutr., 23: 835 (1969).

3. BaIG, H. A., AND Edozien, J. C.: Carbohydrate metabolism in kwashiorkor. Lancet, 2: 662 (1965).

4. BowiE, M. D.: Intravenous glucose tolerance in kwashiorkor and marasmus. S. Afr. Med. J., 38: 328 (1964).

5. Cahill, G. F., Jr., Herrera, M. G., Morgan, A. P., Soeldner, J. S., Steinke, J., Levy, P. L., Reichard, G. A., JR., AND KipNis, D. M.: Hormone fuel interrelationships during fasting. J. Clin. Invest., 45: 1751 (1966).

6. Corndelti, M., Parker, M. L., Reisner, S. H., Forbes, A. E., ANd Daughaday, W. H.: Secretion and metabolism of growth hormone in premature and full-term infants. J. Clin. Endocrinol. Metab., 25: 209 (1965).

7. HADDEN, D. R.: Glucose, free fatty acid, and insulin interrelations in kwashiorkor and marasmus. Lancet, 2: 589 (1967).

8. Hales, C. N., and Randle, P. J.: Immunoassay of insulin with insulin-antibody precipitate. Biochem. J., 88: 137 (1963).

9. Helge, H., Weber, B., and Quabbe, H. J.: Growth hormone release and venepuncture. Lancet, 1: 204 (1969).

10. Huggett, A. St. G., ANd Nixon, D. A.: Use of glucose oxidase, peroxidase, and $o$-dianisidine in determination of blood and urinary glucose. Lancet, 2: 368 (1957).

11. Laron, Z., Mannheimer, S., Nitzan, M., and Goldman, J.: Growth hormone glucose and frec fatty acid levels in mother and infant in normal, diabetic and toxemic pregnancies. Arch. Dis. Childhood, 42: 24 (1967).

12. Lewis, B., Hansen, J. D. L., Wittman, W., Krut, L. H., and STEWART, F.: Plasma free fatty acids in kwashiorkor and the pathogenesis of the fatty liver. Amer. J. Clin. Nutr., 15: 161 (1964). 
13. Lewis, B., Wittman, W., Brut, L. H., Hansen, J. D. L., ANd Ввоск, J. F.: Free fatty acid flux through plasma in protein malnutrition of infants. Clin. Sci., 30: 371 (1966).

14. Marks, V., Haworth, N., and Greenwood, F. C.: Plasma growth-hormone levels in chronic starvation in man. Nature, 208: 686 (1965).

15. Milner, R. D. G.: Malnutrition and the endocrine system in man. Mem. Soc. Endocrinol., 18: 191 (1970).

16. Milner, R. D. G., ANd Wright, A. D.: Plasma glucose, nonesterificd fatty acid, insulin and growth hormone response to glucagon in the newborn. Clin. Sci., 32: 249 (1967).

17. MöNKEBERG, F.: Adaptation to calorie and protein restriction in infants. In: R. A. McCance and E. M. Widdowson: Calorie Deficiencies and Protein Deficiencies, p. 91 (Churchill, London, 1968).

18. Mönkeberg, F., Donoso, G., Oxman, S., Pak, N., and MeneGHeLlo, J.: Human growth hormone and infantile malnutrition. Pediatrics, 31: 58 (1963).

19. Mulinos, M. G., ANd Pomerantz, L.: Pseudohypophysectomy: A condition resembling hypophysectomy produced by malnutrition. J. Nutr., 19: 493 (1940).

20. Netson, W. E.: Textbook of Pediatrics, ed. 7, p. 51 (W. B. Saunders, Philadelphia, 1959).

21. Novak, M.: Colorimetric ultramicro-method for the determination of free fatty acids. J. Lipid Res., 6: 431 (1965).

22. Oxman, S. V., Maccioni, A. S., Zuniga, A. C., SPada, R. D., AND MöNKeberG, F. G.: Disturbances of carbohydrate metabolism in infantile marasmus. Amer. J. Clin. Nutr., 21: 1285 (1968).

23. Pimstone, B. L., Banks, S., and Buchanan-Lee, B.: Growth hormone in protein losing enteropathy. Lancet, 2: 1246 (1968).

24. Pinstone, B. L., Barbezat, G., Hansen, J. D. L., and Murray, P.: Studies on growth hormone secretion in protein-calorie malnutrition. Amer. J. Clin. Nutr., 21: 482 (1968)

25. Pimstone, B. L., Wittman, W., Hansen, J. D. L., and MurRAY, P.: Growth hormone and kwashiorkor. Role of protein in growth hormone homeostasis. Lancet, 2: 779 (1966).
26. Roth, J., Glick, S. M., Yalow, R. S., and Berson, S. A.: The influence of blood glucose on the plasma concentration of growth hormone. Diabetes, 13: 355 (1964).

27. Samols, E., Marri, G., aNd Marks, V.: Promotion of insulin secretion by glucagon. Lancet, 2: 415 (1965).

28. Shelley, H. J., And Thalme, B.: Some aspects of lipid and carbohydrate metabolism in foetal and newborn rabbits. In: G. Joppich and H. Wolf, eds., Stosswechsel des Neugeborenen, p. 178 (Hippokrates Verlag, Stuttgart, 1970).

29. Stein, W. H., AND Moore, S.: The free amino acids of human blood plasma. J. Biol. Chem., 211: 915 (1954).

30. WEstPhaL, O.: Growth hormone-A methodological and clinical study. Acta Pediat. Scand., Suppl. 182 (1968).

31. Winkler, B., Steele, R., Altszuler, N., ANd De Bodo, R. C.: Effect of growth hormone on free fatty acid metabolism. Amer. J. Physiol., 206: 174 (1964).

32. Wright, A. D., Lowy, C., Fraser, T. R., Spitz, I. M., RubeNSTEIN, A. H., AND BERSOHN, I.: Serum growth hormone and glucose intolerance in renal failure. Lancet, 1: 798 (1968).

33. "Insulin binding reagent" and ox insulin (potency 21.6 $\mathrm{U} / \mathrm{mg}$ ) were kindly given by Dr. B. A. L. Hurn, The Wellcome Laboratories, Beckenham, England.

34. Human growth hormone, MRC new preparation R4, was kindly given by Dr. A. Stockell-Hartree, Department of Biochemistry, University of Cambridge, England.

35. The author thanks Professor J. C. Waterlow for his encouragement throughout this study and Miss M. Ceballos for excellent technical assistance.

36. Requests for reprints should be addressed to: The Secretary, MRC Tropical Metabolism Research Unit, University of the West Indies, Kingston 7, Jamaica.

37. Present address: Department of Child Health, University of Manchester, St. Mary's Hospital, Whitworth Park, Man. chester 13, England.

38. Accepted for publication January 14, 1970. 